\section{TÀI LIÊU THAM KHẢO}

1. Công Quyết Thắng (2017), ERAS: Enhanced Recovery After Surgery- Tăng cường hồi phục sau phẫu thuật và vai trò của người làm Gây mê Hồi sức. Hội Gây mê Hồi sức Việt Nam (VSA).

2. Bộ Y Tế (2002), "Dexamethasone". Dược Thư Quốc Gia Việt Nam, 356-357.

3. Nguyển Đình Long (2011), So sánh tác dụng dự phòng và điêu trị nôn và buồn nôn của ondansetron với dexamethasone sau mổ nội soi phu khoa. Luân văn Thạc sĩ. Đại học y Hà Nội.

4. Đố Thanh Hòa (2012), Nghiên cứu tác dụng dự phòng buồn nôn và nôn của dexamethasone đơn thuân hoặc kết hợp với ondansetron sau gây tê tủy sống trong phấu thuât chi dưới. Y hoc thực hành, 841.

5. Nguyễn Đức Lam (2013), Đánh giá hiệu quả của phương pháp gây tê tủy sống và gây tê tủy sống - ngoài màng cứng phối hợp để mổ lấy thai ở bệnh nhân tiền sản giật nặng. Luận án tiến sĩ y hợc, Đại học Y Hà Nội.

6. Đố Văn Lợi (2017), Nghiên cứu hiệu quả giảm đau trong chuyển da của phơơng pháp gây tê ngoài màng cứng do và không do bệnh nhân tự điêu khiển. Luân an tiến sĩ y hoc, Đai hợ y Hà Nôi.

7. Nguyển Hoàng Ngọc (2010), Đánh giá hiệu quả của sự phối hợp bupivacain liêu thấp với morphin khồng có chẩt bảo quản trong gây tê tủy sống để mổ lấy thai và giảm đau sau mổ, Luận văn Chuyên khoa cấp II, chuyên ngành GMHS, Trường Đại học Y Hà Nội 2010.

8. Trân Văn Quang, Bừi İ́ch Kim (2011), Đánh giá hiệu quả giảm đau trong chuyên dạ đẻ bằng gây tế ngoài màng cứng levobupivacain phối hợp với fentanyl ở các nông đô và liều lướng khác nhau. Luận văn thạc sĩ y học, Đại học Y Hà Nội.

9. Watcha, M.F., P.F. White (1992), Postoperative nausea and vomiting. Its etiology, treatment, and prevention. Anesthesiology, 77(1): 162-84.

\title{
BÊNH CƠ KHÁNG SRP NHỮNG TRƯỜ'NG HỢP ĐẦU TIÊN TẠI VIỆT NAM
}

\section{TÓM TẮT}

Bệnh cơ kháng SRP là thể bênh cơ hoại tử qua trunq qian miễn dich liên kết với khánq thể kháng SRP (anti-signal recognition particle). Đây là một bệnh chưa từng được nhắc tới trong các báo cáo y khoa ở nước ta. Chúng tôi mô tả các đặc điểm lâm sàng, cận lâm sàng và đáp ứng điêuu trị của 3 trường hợp bệnh cơ kháng SRP. Cả 3 trường hớp đều có lâm sàng điển hình và xét nghiệm kháng thể kháng SRP dương tính, trong đó 2 trường hợp có biến đổi mô bệnh học phù hợp và 1 trường hợp không điển hình. Một trong số ba bểnh nhân có đáp ứng tốt với điều trị Rituximab, 1 bệnh nhân đáp ứng hạn chế với điều trị 2 thuốc ức chế miễn dịch phối hợp, 1 bệnh nhân không đáp ứng với Rituximab và dung nap kém với thuốc ức chế miễn dịch. Chúng tôi lưu ý tới vai trò quan trọng của xét nghiệm kháng thể trong chẩn đoán, và những khó khăn trong điều trị bệnh cơ kháng SRP, một thể bệnh cơ còn rất mới ở Viêt Nam.

Tư khoá: bệnh cơ kháng SRP, khăng thể kháng SRP, bệnh cơ hoại tử qua trung gian miễn dịch

\section{SUMMARY}

\section{ANTI-SRP MYOPATHY - THE FIRST CASES IN VIETNAM}

Anti-SRP myopathy is the subtype of immune mediated necrotizing myopathy which is associated

\section{*Bệnh viện chuyên khoa Ngoại Thần kinh Quốc tế} **Đai hoc Y Dước TP Hồ Chí Minh

Chịu trách nhiệm chính: Phan Hoàng Phương Khanh Email: bsphuongkhanhntk@gmail.com

Ngày nhận bài: 22.12.2020

Ngày phản biên khoa hoc: 29.01.2021

Ngày duyệt bài: 4.2.2021 with anti-sianal recognition particle (SRP) antibody. This disease has never been mentioned in the medical reports in Vietnam. In this paper, the clinical, laboratory and therapeutic characteristics of three cases with anti-SRP myopathy are described. All the cases had typical clinical features and serum positive for anti-SRP antibody. Two cases had appropriate histopathological changes and the other had atypical changes. One patient responded well to Rituximab, one had a limited response to two combined immunosuppressants, and the third did not respond to rituximab and had poor tolerance to immunosuppressants. The important role of antibody testing for diagnosis and the problems with treatment for this very newly known anti-SRP myopathy in Vietnam should be emphasized.

Keywords: anti-SRP myopathy, anti-signal recognition particle (SRP) antibody, immune mediated necrotizing myopathy.

\section{I. ĐẶT VẤN ĐỀ}

Nhóm bệnh viêm cơ tự miễn gồm nhiều thể bệnh, trong đó có bệnh cơ hoại tử qua trung gian miễn dịch (immune mediated necrotizing myopathy - IMNM). Thể bệnh này mới được nhắc đến trong khoảng hơn một thập kỷ nay, nhưng là một trong các thể bểnh viêm cơ tư miễn hay gặp. Trên thế giới trước đây và tại Việt Nam hiện nay, IMNM dễ bị chẩn đoán nhầm với các thể viêm cơ tự miễn khác. Có hai kháng thể phổ biến nhất liên quan tới IMNM là kháng SRP (anti-signal recognition particle) và kháng HMGCR (anti-3-hydroxyl-3 methylglutarylcoenzyme A reductase $)^{(2,5)}$. Trong thời gian vừa 
qua, chúng tôi ghi nhận 3 bênh nhân dương tính với kháng thể kháng SRP. Chúng tôi mô tả các đặc điểm lâm sàng, cận lâm sàng, giải phẫu bệnh, xét nghiệm kháng thể và đáp ứng điều trị của 3 trường hợp này, nhằm giúp hiểu rõ hơn về một bệnh lý còn khá mới lạ ở Việt Nam.

\section{MÔ TẢ CÁC TRƯỜNG HỢP LÂM SÀNG:}

1. Trường hợp thứ nhất: Bệnh nhân nữ, 58 tuổi, bắt đầu yếu cơ tăng dần cách 10 tháng, sau 2 tháng yếu cơ tứ chi nặng, được chẩn đoán viêm đa cơ và điều trị trong 8 tháng liền bằng prednison và mycophenolate mofetil. Yếu cơ lúc đầu có cải thiện ít nhưng sau đó không đõ thêm. Một tháng trước nhập viện bệnh nhân nói chuyện bị hụt hơi, khi ngồi ghế không tự đứng lên, phải di chuyển bằng xe lăn. Tiền sử không dùng thuốc nhóm statin và gia đình không có tiền sử bệnh tương tự.

- Khám lâm sàng: yếu cơ đối xứng, gốc chi nặng hơn ngọn chi, điểm sức cơ tổng MRC (Medical Research Council sum score) là 40/60 điểm. Teo nhe các cơ gốc chi. Sức cơ gập-duỗi cổ $5 / 5$, sức nuốt $3 / 3$ (không nuốt nghẹn cả với thức ăn đă̆c). Test đếm số to từ 1 tới 50 : đếm được tới 12. Không rối loan cảm giác và phản xạ gân xương, không dấu bệnh lý tháp. Không biểu hiện tổn thương da.

- Cân lâm sàng: CK (Creatine kinase) 4154 U/L, LDH (lactate dehydrogenase) 996 U/L. Điên tâm đồ bình thường. Cộng hưởng từ cơ có teo cơ đối xứng kèm thoái hóa mõ và tăng tín hiệu rải rác, ưu thế ở cơ khép, mông lớn, mông bé và vùng đùi sau. Chẩn đoán điện cho hình ảnh bệnh cơ nhưng không có điện thế tự phát.

- Sinh thiết cơ: teo sợi cơ rải rác, thoái hóa sợi cơ nhẹ, hoại tử không rõ, không thâm nhập tể bào viêm, hóa mô miễn dịch $\mathrm{CD} 4(-), \mathrm{CD} 8(-)$.

- Xét nghiệm bộ kháng thể: dương tính với kháng thể kháng SRP (anti- SRP +).

- Bênh nhân được điều trị bằng hai thuốc ức chế miễn dịch phối hợp (mycophenolate mofetil $2000 \mathrm{mg} /$ ngày + methotrexate 15 mg/tuần). Sau 3 tháng, sức cơ cải thiện với tổng MRC tăng nhẹ (42/60 điểm), test đếm số to $1-50$ đếm được tới 21, CK 3472U/I. Trong 2 tháng tiếp sau khổng có cải thiện gì thêm. Bệnh nhân được điều trị thêm bẳng Rituximab $500 \mathrm{mg}$ truyền trong 4 đợt liên tiếp cách nhau một tháng, trong khi vẫn duy trì thuốc ức chế miễn dịch. Sau mổi lần truyên Rituximab 1 tháng, đánh giá lại các chỉ số lâm sàng và cận lâm sàng đều có cải thiện. Cụ thể sau lần truyền thứ nhất, thứ hai và thứ ba, điểm tổng MRC lần lượt là 42/60, 45/60, và $51 / 60$; đồng thời test đếm to $1-50$ khá dần, lần lượt là đếm tới 33,37 , và 36 . Nồng độ CK huyết thanh lần lượt là 1466, 1102 và $1128 \mathrm{U} / \mathrm{l}$. Sau khi truyền đủ 4 lượt Rituximab, điểm tổng MRC 52/60, tư chải đâu và đi bô, nhưng chưa thể leo gác và ngồi xổm đứng dậy, test đếm to 1-50 được tới 43, CK 850U/L. Kiểm tra sau 2 tháng tiểp thấy điểm tổng MRC $52 / 60$, CK còn 460U/l.

2. Trường hợp thứ hai: Bệnh nhân nữ, 67 tuổi, tiền sử dùng statin nhưng đã ngưng hai năm do tăng men gan. Bệnh nhân bị yếu tứ chi nặng sau 1 tháng và yếu tăng dần một năm nay, đã từng được chẩn đoán bệnh viêm đa cơ, nhưng bệnh nhân không tuân thủ điều trị. Một tháng cách nhập viện, bệnh nhân bị yếu tứ chi năng và không thể tự đi đứng, không tự chải đầu, bị nuốt nghẹn.

- Khám lâm sàng: Yếu cơ tứ chi ưu thế gốc chi, điểm tổng MRC 41/60. Teo cơ đùi, vai, cánh tay hai bên. Sức cơ gập cổ $4 / 5$, duỗi cổ $5 / 5$. Sức nuốt 2/3 (nuốt nghẹn với thức ăn đặc). Không rối loạn cảm giác, không dấu hiệu tháp. Không biểu hiện tổn thương da.

- Cận lâm sàng: CK 834 U/L, LDH 684 U/L, tốc độ máu lắng $50 / 1$ giờ và $94 \mathrm{~mm} / 2$ giờ. Điện tâm đồ bình thường. Chẩn đoán điện có hình ảnh bệnh cơ kèm tăng tính kích thích màng (irritable myopathy).

- Sinh thiết cơ: teo sợi cơ, hoại tử sợi cơ, sợi cơ tái tạo, thâm nhiễm mõ , xơ hóa nội cơ, tế bào lympho nội cơ (endomysial). Hóa mổ miến dịch: CD4 (+), CD8 (+).

- Xét nghiệm bộ kháng thể: anti SRP (+), anti PL7 (+).

- Bênh nhân được điều trị bằng prednisone $(60 \mathrm{mg} / \mathrm{ngày})$ và methotrexate $(15 \mathrm{mg} /$ tuần), bệnh nhân không đồng ý dùng IVIG( Intravenous Immunoglobulin). Sau 6 tuần, sức cơ tay chân cải thiên, điểm tổng MRC 42/60, hết nuốt nghen. Khi giảm liều prednisone thì bi nuốt nghẹn trở lại, nên được thêm azathioprine $(100 \mathrm{mg} / \mathrm{ngày})$. Trong 6 tháng duy trì điều tri phối hợp, điểm tổng MRC lúc đầu tăng nhẹ, về sau ổn định mức 44/60, sức nuốt dao động từ $2 / 3$ tới $3 / 3$, sức cơ gập và duỗi cổ: $5 / 5$.

3. Trường hợp thứ 3: Bệnh nhân nữ, 67 tuổi, có tiền sử u màng não liểm đại não, được điều trị Gamma- knife cách 1 năm. Trong 5 tháng trước nhập viện bệnh nhân bị yếu cơ tứ chi tăng dần, cách nhập viện 3 tháng bị nuốt nghẹn, khó thở khi nằm.

- Khám lâm sàng: Yếu cơ tứ chi, ưu thế ở gốc chi, điểm tổng MRC $36 / 60$, teo cơ vùng đùi và 
vai. Sức cơ gập và duỗi cổ $4 / 5$. Sức nuốt $1 / 3$ (nuốt nghẹn với thức ăn lỏng). Phản xạ gân xương $2(+)$, không rối loạn cảm giác, không dấu hiệu tháp. Không bị khổ mắt, khô miệng và không biểu hiện tổn thương da.

- Cận lâm sàng: CK 2166 U/l, LDH 1277U/l, tốc độ lắng máu $5 \mathrm{~mm} / 1$ giờ và $10 \mathrm{~mm} / 2$ giờ. ANA (+), antids DNA (-), RF $20 \mathrm{ul} / \mathrm{mL}$. Điện tâm đồ bình thường. Chẩn đoán điện có hình ảnh bệnh cơ tăng tính kích thích màng (irritable myopathy).

- Sinh thiết cơ: teo sợi cơ, sợi hoại tứ, sợi tái tạo, thâm nhiễm mõ̃, xơ hóa nội cơ, tế bào lympho ít, rõ nhất ở khoảng trong cơ (endomysium), ngoài ra có ở quanh mạch, vùng quanh cơ (perimysium). Hóa mô miễn dịch: CD4 $(+), \operatorname{CD} 8(+)$.

- Xét nghiệm bộ kháng thể: anti SRP (+), anti SSA/Ro (+).

- Bênh nhân được điều trị bằng prednisone và methotrexate, sau 2 tháng thì bớt nuốt nghẹn (sức nuốt 2/3), hết khó thở, điểm tổng $M R C$ 37/60. Do bệnh nhân bị loãng xương và xẹp đốt sống L2-L3, nên được giảm nhanh liều prednisone và thêm azathioprine $100 \mathrm{mg} / \mathrm{ngày}$. Tuy nhiên sau 2 ngày phải ngừng azathioprine do bị nặng ngực. Bệnh nhân ho khạc kém, nuốt nghẹn trở lại, được truyền thêm Rituximab $500 \mathrm{mg} /$ đợt trong 4 đợt liên tiếp cách nhau 1 tháng. Sau 4 đợt, bệnh nhân bớt nuốt nghẹn, bớt khó thở nhưng sức cơ tay chân không cải thiện. Bệnh nhân bị giảm bạch cầu hạt nên ngưng cả Methotrexate, chỉ còn duy trì prednison $(10 \mathrm{mg} / \mathrm{ngày})$ và tăng liều acid folic. Bệnh nhân không đồng ý dùng IVIG.

\section{BÀN LUÂN}

Bệnh cơ kháng SRP chiếm một tỉ lệ không nhỏ trong các trường hợp viêm cỡ. Nghiên cứu trên 460 bệnh nhân viêm cơ tự miễn ở Nhật Bản cho thấy IMNM chiếm 39\% các trường hợp viêm cơ, và trong số bị IMNM thì bệnh cơ kháng SRP chiếm $39 \%$, bệnh cơ kháng HMGCR $26 \%$ và kháng thể âm tính $35 \%{ }^{(5)}$. Cả 3 bệnh nhân của chúng tôi đều có lâm sàng phù hợp với yếu cơ gốc chi tiến triển bán cấp và $\mathrm{CK}$ tăng cao. Triệu chứng nuốt khó (ở 2 bệnh nhân) cũng là triệu chứng thường gặp trong bệnh cơ kháng SRP $\left(52,1 \pm 30 \%{ }^{(2,5)}\right)$, trên 2 bệnh nhân này cũng có biến đổi mô học cơ đặc hiệu cho IMNM. Riêng bệnh nhân thứ nhất biến đổi mô học là không đặc hiệu, và cũng không thấy biểu hiện của viêm cơ. Trong điều kiện chưa có thuốc nhuộm hóa mô miễn dịch đặc hiệu hơn, xét nghiệm kháng thể kháng SRP dương tính đã giúp xác định chẩn đoán và quyết định lựa chọn điều trị cho bệnh nhân này.

Tiên lượng của bệnh cơ kháng SRP thường kém, chỉ khoảng $50 \%$ bệnh nhân hồi phục sức cơ về bình thường sau 4 năm điều trị ${ }^{(1)}$. Chỉ định điều trị Rituximab cho bệnh cơ kháng SRP sau 6 tháng không đáp ứng với điều trị ức chế miễn dich, đã được đồng thuân ở hôi thảo thứ 224 của Trung tầm thân kinh cơ Chẩu Âu (ENMC) ${ }^{(4)}$. Một số chuyên gia đã cho biết nếu dùng IVIG ngay lúc khởi đầu ở các trường hợp nặng thì sẽ có hiệu quả điều trị cao hơnn ${ }^{(4)}$. Cả 3 bệnh nhân của chúng tôi đều không cải thiện khi điều trị prednisone phối hợp với một loại thuốc ức chể miễn dịch. Bệnh nhân thứ nhất chỉ cải thiện triệu chứng đáng kể khi được dùng rituximab phối hợp với hai thuốc ức chế miễn dịch. Bệnh nhân thứ hai có đáp ứng ít với điều trị 2 loại thuốc ức chế miễn dịch, và không có điều kiện để dùng IVIG hay rituximab. Bệnh nhân thứ 3 không đáp ứng với rituximab, bị giảm bạch cầu hạt khi dùng Methotrexate và không dung nạp azathioprine, bênh nhân không đồng ý dùng IVIG. Bệnh nhân này ngoài kháng thể kháng $\mathrm{SRP}$, còn dương tính rõ với một kháng thể nữa là kháng thể kháng SSA/Ro. Theo y văn, Nakamura đã mô tả một trường hợp dương tính với cả hai kháng thể trên, bênh nhân bi yếu cơ nặng nề và đáp ứng điều trị kém, có thể sự có mặt của cả 2 kháng thể là nguy cơ làm bệnh nặng hơn ${ }^{(3)}$.

\section{KẾT LUÂN}

Theo hiểu biết của chúng tôi, 3 trường hợp của chúng tôi là các trường hợp đầu tiên tại Việt Nam được xác định bị bệnh cớ hoại tử qua trung gian miển dịch (IMNM) liên kết với kháng thể kháng SRP (bệnh cơ kháng SRP). Trong điều kiện còn khó khăn, khi giải phẫu bệnh của chúng ta chưa có hoá mô miển dịch đặc hiệu, thì xét nghiệm kháng thể là rất quan trọng, đôi khi giúp quyết định chẩn đoán.

Điều trị bệnh cơ kháng SRP là phức tạp và khó khăn. Các trường hợp kháng trị cần dùng tới IVIG và rituximab, và phối hợp từ hai loại thuốc ức chế miễn dịch trở lên. Tuy vậy, thực tế ở Việt Nam, chúng ta phải ứng dụng linh động tùy theo từng cá thể. Chúng tôi đề nghị trong thực hành thần kinh học, nên lưu ý về chẩn đoán và điều trị thể bệnh cơ còn khá mới lạ này, nhằm có được lựa chọn tối ưu cho bệnh nhân.

\section{TÀI LIÊU THAM KHẢO}

1. Pinal-Fernandez $\mathbf{I}$, Mammen AL. Spectrum of immune-mediated necrotizing myopathies and their treatments. Curr Opin Rheumatol 2016; 
28:619-24.

2. Suzuki S, Hayashi YK, Kuwana M, Tsuburaya R, Suzuki N, Nishino I. Myopathy associated with antibodies to signal recognition particle: disease progression and neurological outcome. Arch Neurol 2012; 69: 728-32.

3. Nakamura, T. Coexistence of Anti-SRP and Anti-SS-A/Ro Antibodies in Inflammatory Myopathy: Does the Association Occur by Chance? A Case Report. SN Compr. Clin. Med 2020; 2: 822-828.
4. Allenbach $\mathbf{Y}$, Mammen $A$, Benveniste $\mathbf{O}$, Stenzel W $224^{\text {th }}$ ENMC International Workshop: Clinico-sero-pathological classification of immune mediated necrotizing myopathies. Neuromuscular Disorders 2018; 28: 87-99.

5. Watanabe Y, Uruha A, Suzuki S, Nakahara J, Hamanaka K, Takayama K, et al. Clinical features and prognosis in anti-SRP and antiHMGCR necrotising myopathy. J Neurol Neurosurg Psychiatry 2016; 87:1038-44.

\section{SO SÁNH GIỮA CHỤP XA HÌNH XƯƠNG VÀ CHỤP CẮT LỚP VI TÍNH TRONG PHÁT HIÊ̂N DI CĂN XƯO'NG Ở BÊNNH NHÂN UNG THƯ BIỂU MÔ TẾ BÀO GAN}

\section{TÓM TẮT}

Mục tiêu: So sánh hiêu quả chẩn đoán di căn xương bằng chụp xạ hình xương (BS) với Technetium99m methylene diphosphonate (Tc-99m MDP) và chụp cắt lớp vi tính $(\mathrm{CT})$ ở bệnh nhân ung thư biểu mô tế bào gan (HCC) có nghi ngờ di căn xương. Phương pháp: Nghiên cứu tiến cứu trên 57 bệnh nhân HCC. Độ chính xác của $\mathrm{BS}$ và $\mathrm{CT}$ được xác định bằng cách so sánh với kết quả di căn tiến triển và chỉ định điều tri giảm nhẹ sau đó. Kết quả: Nghiên cứu này bao gồm 48 nam và 9 nữ, tuổi trung bình $60,5 \pm 12,9$. Lý do chụp xạ hình xương: tầm soát di căn $(54,4 \%)$, đau xương: $29,8 \%$, yếu chi: $14 \%$, sờ thây khối trên thành ngực: $1,8 \%$. Tî lệ phát hiện di căn xương bằng $\mathrm{BS}$ $(45,6 \%)$ cao hơn so với CT $(29,8 \%), p=0,001$. Có 23 vùng di căn trên $\mathrm{CT}$, có xu hướng phát hiện tốt hơn ở cột sống: $14 / 23$, xương chậu: $5 / 23$ và 45 vùng trên BS, có xu hướng phát hiện tổn thương tốt hơn ở cột sống: 19/45, xương sườn: 12/45. Theo kết quả theo dõi và điều trị giảm nhe bằng SBRT, phát hiện tổn thương xương di căn bẳng $\mathrm{CT}$ : đô nhay $72,2 \%$, độ đặc hiệu $89,7 \%$, giá trị dự đoán dương tính: 76,5\%, giá trị dự đoán âm tính $87,5 \%$, độ chính xác $84,2 \%$; phát hiện tổn thương xương di căn bằng bằng BS: độ nhạy $100 \%$, độ đặc hiệu 79,5\%, giá trị dự đoán dương tính $69,2 \%$, giá trị dự đoán âm tính $100 \%$, độ chính xác $86,0 \%$. Kết luân: Chụp xa hình xương có độ chính xác tốt hơn so với chụp cắt lớp vi tính trong việc phát hiện tổn thương xương do HCC di căn, nhưng để xác định di căn xương, hỏi bệnh cẩn thận, khám lâm sàng kĩ và thực hiện nhiều phương pháp chụp xương là rất quan trọng.

Tư khóa: Ung thư biểu mô tế bào gan, di căn xương, chụp xạ hình xương

\section{${ }^{1}$ Trường Đại học Y Dược Thái Nguyên}

²Bênh viện trung ương quân đội 108

Chịu trách nhiệm chính: Đồng Đức Hoàng

Email: Drhoang85@gmail.com

Ngày nhận bài: 21.12.2020

Ngày phản biện khoa học: 27.01.2021

Ngày duyệt bài: 2.2.2021
Đồng Đức Hoàng1, Lê Thị Ánh Tuyết ${ }^{2}$

\section{SUMMARY}

COMPARISON BETWEEN BONE SCINTIGRAPHY AND COMPUTED TOMOGRAPHY FOR THE

DETECTION OF BONE METASTASES IN HEPATOCELLULAR CARCINOMA

Aim: To compare the diagnostic accuracy of bone scintigraphy (BS) and computed tomography (CT) in detecting skeletal metastases for hepatocellular carcinoma (HCC) patients with suspicious bone metastasis. Methods: A prospective study was carried out in $57 \mathrm{HCC}$ patients. The accuracies of BS and $\mathrm{CT}$ were determined by comparing with final diagnosis with criteria obvious progression of the lesion revealed from the follow-up examinations and treatment. Results: This study included 48 male and 9 female, mean age $60.5 \pm 12.9$. Reasons for bone scintigraphy: Tumor extent surveillance: $54.4 \%$, bone pain: $29.8 \%$, limb weakness: $14 \%$, palpable chest wall mass: $1.8 \%$. There was a significant difference in bone metastatic detection between BS (45.6\%) and CT $(29.8 \%), p=0.001$. There were 23 metastatic regions on $\mathrm{CT}$, tended to identify more positive lesions in the spine: $14 / 23$, pelvis: $5 / 23$; 45 regions in $B S$, tended to show more positive lesions in the spine: 19/45, ribs: 12/45. According to the follow-up result and palliative treatment by SBRT, for detecting metastatic bone lesions by CT: Sensitivity $=72.2 \%$, Specificity $=89.7 \%$, Positive Predictive Value = $76.5 \%$, Negative Predictive Value $=87.5 \%$, Accuracy $=84.2 \%$; by BS: Sensitivity $=100 \%$, Specificity = $79.5 \%$, Positive Predictive Value $=69.2 \%$, Negative Predictive Value $=100 \%$, Accuracy $=86.0 \%$. Conclusion: BS has significantly better accuracy than $\mathrm{CT}$ in detecting metastatic HCC bone lesions, but to determine bone metastases, careful history taking, meticulous physical examination and perfoming many bone scan methods are very important.

Keyword: Hepatocellular carcinoma, Bone metastasis, Tc-99m MDP bone scintigraphy

\section{I. ĐẶT VẤN ĐỀ}

Ung thư biểu mô tế bào gan (HCC) là bệnh ác tính tại gan gặp nhiều nhất ở người trưởng 